\title{
A INTERSECÇÃO DA AUTORIDADE ENTRE ESTADO E RELIGIÃO
}

Franciele Vaz de Souza ${ }^{1}$

\section{Introdução}

Ao aproximar as teorias de Maquiavel e Lutero, o trabalho tem como objetivo delimitar a relação de poder entre o Estado e a Igreja: em seu tratado sobre $O$ príncipe, Maquiavel defende a supremacia do homem sobre a religião; nos textos sobre Da liberdade do cristão e Sobre a autoridade secular, Lutero defende a preeminência do governo espiritual sobre o terreno. O presente trabalho tem como foco colocar em equiparação essas duas alçadas de autoridade. Maquiavel, como chanceler da República de Florença, estava situado numa condição de justificar o poder sem precedentes conferido ao homem; posteriormente, já destituído de seu cargo, defende a centralização do poder em uma só pessoa, como forma de governo mais indicada para defender as cidades-Estado italianas das constantes invasões, para evitar, assim, maior instabilidade - e consequente fragilidade - dos inúmeros reinados espalhados pelo território italiano. É possível perceber que, ao depositar no homem toda a confiança, Maquiavel coloca em segundo plano a intervenção da Igreja Católica nos assuntos de governo. Também descrê da sorte ou da fortuna como medida eficiente para se manter à frente do poder. Em contrapartida, Lutero defende o predomínio da autoridade eclesiástica sobre a autoridade secular, ou seja, que o governo divino, espiritual e eterno esteja num patamar superior quando comparado a preceitos mundanos e corruptíveis, do âmbito de um príncipe terreno.

Palavras-chave: Estado. Igreja. Autoridade. Vínculo.

\section{Desenvolvimento}

Nicolau Maquiavel (1469 - 1527) dedicou a publicação de O Príncipe (1513) a Lourenço II de Médici. Como bem aponta Skinner, Maquiavel dedica a obra aos Médici com o objetivo de retomar seu cargo em Florença. Os golpes de Estado eram frequentes nos inúmeros principados da Itália - apontando um cenário de instabilidade e gerando, por conseguinte, fraqueza militar e política. Cenário este que se modificaria, segundo Maquiavel, se um só príncipe comandasse todas as terras dispersas.

\footnotetext{
Assim, tendo ficado como sem vida, espera a Itália aquele que lhe possa curar as feridas. (...). Vê-se, ainda, que se acha pronta e disposta a seguir uma bandeira, uma vez que haja quem a levante (...). Tome, pois, a vossa ilustre casa esta tarefa com aquele ânimo e com aquela fé com que se esposam as boas causas, a fim de que, sob o seu brasão, esta pátria seja enobrecida (MAQUIAVEL, 1983, p. 107-10)
}

\footnotetext{
${ }^{1}$ Graduanda em Filosofia, pela Universidade Estadual Paulista (UNESP) - Câmpus de Marília. E-mail: fraanvaz@hormail.com. Pré-projeto de monografia para Trabalho de Conclusão de Curso, sob orientação da profa dra Ana Portich.
} 
Maquiavel baseou-se em exemplos de diversas figuras históricas de príncipes consagrados ou fracassados, apontando o que deveria ser feito ou não deveria, para conseguir o primeiro e evitar o segundo:

\begin{abstract}
Agora, quanto ao exercício do pensamento, o príncipe deve ler histórias de países e considerar as ações dos grandes homens, observar como se conduziram nas guerras, examinar as razões de suas vitórias e derrotas, para poder fugir destas e imitar aquelas; sobretudo, deve fazer como teriam feito em tempos idos certos grandes homens, que imitavam o que antes deles haviam sido glorificados por suas ações, como consta que Alexandre Magno imitava a Aquiles, César a Alexandre, Cipião a Ciro. (...) Um príncipe sábio deve observar estas coisas e nunca ficar ocioso nos tempos de paz; deve, sim, inteligentemente, ir formando cabedal de que se possa valer nas adversidades, para estar sempre preparado a resistir-lhes. (MAQUIAVEL, 1983, pp. 61-62).
\end{abstract}

Dessa forma, segundo Maquiavel, há dois meios para tornar-se um príncipe de grande notoriedade: pela fortuna e pelo valor $(v i r t u ̀)^{2}$. Para elucidar bem, o autor cita dois casos: Francesco Sforza, que subiu ao poder através do valor, tornou-se duque de Milão de maneira trabalhosa, mas, quando conquistou o posto, conseguiu governar tranquilamente. Já César Bórgia, pelo fato de ser filho de Rodrigo Bórgia (ou papa Alexandre VI), não tinha nada a temer, a não ser a iminência da morte e a pressão de exércitos inimigos. Seu poder teria passado por cima de tais obstáculos tranquilamente, porém, as próprias pessoas em que ele acreditava serem confiáveis traíram-no. Se tivesse aniquilado todos os seus inimigos, e aproximado apenas os de sua confiança, seu poder não se dissiparia desta forma.

Portanto, se julgas necessário, num principado novo, assegurar-te contra os inimigos, conquistar amigos, vencer ou pela força ou pela astúcia, fazer-te amado e temido do povo, ser seguido e respeitado pelos soldados, extinguir os que podem ou devem ofender, renovar as antigas instituições por novas leis, ser severo e grato, magnânimo e liberal, dissolver a milícia infiel, criar uma nova, manter amizades dos reis e dos príncipes, de modo que te sejam solícitos no benefício e tementes de ofender-te, repito que não encontrarás melhores exemplos que nas ações do duque. (MAQUIAVEL, 1983, p. 32, grifo meu)

Logo, se uma das formas de o príncipe reinar bem é através da astúcia, Maquiavel destila críticas àqueles que acreditam apenas nos desígnios de Deus e da sorte para alcançar seus objetivos, apontando a clara preponderância do homem sobre o propósito divino:

Estou convencido de que é melhor ser impetuoso do que circunspecto, porque a sorte é mulher e, para dominá-la, é preciso bater-lhe e contrariá-la. (MAQUIAVEL, 1983, p. 105).

\footnotetext{
${ }^{2}$ Vale ressaltar que, enquanto conceito retomado da Antiguidade, a virtù aqui trabalhada não tem vínculo algum com a virtude cristã .
} 
Por não ser unificada, não ter chefe, ter exército mercenário e todos os problemas que a acometiam, a Itália fora devastada e "facílimo foi, por isso, a Carlos, rei de França, conquistar a giz a Itália inteira”.(MAQUIAVEL, 1983, p. 50). Maquiavel acreditava ser possível a Itália resistir, com a condição de que um príncipe como Lourenço II seguisse seus conselhos. Como aponta Skinner, o humanismo renascentista, "Acima de tudo, contribuiu para se voltar maior interesse para a personalidade do indivíduo. O homem passou a sentir-se em condições de utilizar sua liberdade, de modo a fazer-se arquiteto e explorador de sua própria pessoa". (SKINNER, 1996, p. 119). Sobretudo no momento delicado que a Itália se encontrava, um príncipe dotado de real virtù seria reverenciado.

Contrariamente, o alemão Martinho Lutero (1483 - 1546) expõe uma visão inferior do homem, quando comparado com o ser divino.

Será analisada pormenorizadamente a obra Sobre a Autoridade Secular (1523), de Lutero, livro que homenageia seu protetor, Frederico, o Sábio, Eleitor da Saxônia, um dos príncipes que protegeu Lutero após ser excomungado da Igreja Católica, em 1521.

Após ter mostrado os meios de ser um cristão, Lutero mostra o que não deve ser feito para tornar-se cristão, já que nos escritos que dizia o que devia ser feito, as pessoas haviam reagido tão mal. Explicita ainda sua indignação à subserviência dos homens a outros homens (que se autoproclamam donos do poder e da verdade), sobretudo no episódio em que príncipes mandaram à queima todas as traduções da Bíblia feitas por Lutero. "Eles tiveram a temeridade de colocarem-se no lugar de Deus, de tornarem a si mesmos senhores das consciências e das crenças [fé] (...). De submeter a vontade de Deus a seus próprios e arbitrários caprichos" (LUTERO, 2005, pp. 6-7).

A humanidade, para Lutero, está dividida em duas. A saber: reino de Deus (eclesiástico) e reino do mundo (secular). Se as pessoas se orientassem pelos escritos de Deus, sobretudo nas passagens do Evangelho, não precisariam se orientar pela autoridade secular, quiçá pela sua Espada ${ }^{3}$. Assim, se todos acreditassem e tivessem fé na palavra, não haveria necessidade de leis, príncipes, reis, ou qualquer outro tipo de poder que comande os demais, apenas o de Deus.

\footnotetext{
3 "Para Lutero, trata-se do símbolo, do emblema e da substância da autoridade secular (...) e não há duvida de que Lutero se refere à 'espada' em seu sentido literal". "Introdução". In LUTERO. Sobre a autoridade secular, p. XXIV.
} 
Logo, cada governo - espiritual ou secular - possui sua respectiva lei. O governo secular pode tratar de questões como bens, coisas materiais e tudo que for mundano, mas, sobre a alma, somente Deus pode interferir. Ou seja, leis seculares não são aplicáveis, de modo algum, às questões da alma. E se o governante mundano o faz, está excedendo o limite. Portanto, as pessoas devem ter fé naquilo que Deus disse, e não nos papas, bispos e pessoas interessadas apenas num alto cargo. As decisões espirituais não competem a pessoas com ocupações seculares, as quais, por sua vez, não devem se ocupar de assuntos que cabem somente a Deus. Intitulam-se de "príncipes cristãos", sendo que ordenam que os súditos façam apenas o que eles pensam e dizem, sem vestígio de qualquer palavra de Deus. Um príncipe, rei ou imperador não pode achar-se no direito de mandar naquilo que é interno a cada homem: o pensamento, a fé. Cada um sabe de si e o que é melhor para acreditar. Apenas Deus conhece esses mistérios internos (nem a Igreja pode fazê-lo). A autoridade secular não é diminuída caso seu súdito não aja e pense como o rei. Notavelmente, há dois tipos de autoridades, mas Lutero sempre exalta a superioridade do governo de Deus (Cristo) sobre o governo do homem:

\footnotetext{
Aqueles que não têm fé não são cristãos e não pertencem ao reino de Cristo e sim ao reino do mundo, para serem coagidos e regidos pela Espada e pelo governo exterior. Os cristãos [por outro lado] fazem tudo o que é correto, sem nenhuma coação, e têm tudo de que precisam na Palavra de Deus. (LUTERO, 2005, p. 53).
}

"Ora, quem quer que deseje ser um príncipe cristão deve abandonar qualquer pretensão de dominar as pessoas e de usar a força" (LUTERO, 2005, p. 54), ponto que se contrapõe à doutrina maquiavélica, adepta ao uso de força, se preciso for. Segundo Lutero, o príncipe cristão deve usar as leis sabiamente e estar preparado para um possível imprevisto. As leis são aplicáveis até que a necessidade diga o contrário; ela nunca deve passar por cima das necessidades, caso passe, não há nada de bom, além de tirania. $\mathrm{O}$ cristão “(...) deve agir com respeito e não confiar nem em livros mortos nem em cabeças vivas, mas exclusivamente em Deus (...)" (LUTERO, 2005, p. 56). Esta é outra contraposição clara de Lutero aos escritos de Maquiavel, que se utiliza da história para fundamentar seus argumentos n'O Príncipe, confiando, dessa maneira, nos ditos homens mortos, e mais ainda nos que estão vivos, pois neles é que Maquiavel estava confiando, sobretudo nos Médici, para alavancar a situação da Itália.

\section{Os liames entre as teorias de autoridade de Maquiavel e Martinho Lutero.}


Mesmo que Maquiavel argumente que o homem seja superior a Deus, e tudo que faça seja possível e justificável, ao passo que Martinho Lutero, com sua divisão dos reinos em espiritual e secular, sobreponha o primeiro ao segundo, eles centram suas teorias nas relações que a Igreja Católica ou a Igreja Evangélica deveriam ter com o Estado.

Maquiavel em diversas passagens do livro $O$ Príncipe demonstra como os príncipes foram bem ou mal sucedidos, e o que deveriam ou não ter feito; e, em grande parte de suas análises sobre fatos históricos, papas apoiavam os reis e, em alguns casos, o apoio ou a recusa de ajuda era determinante para o fracasso ou ascensão do príncipe. Como no caso do rei da França, Luís XII, que, ao ajudar o Papa Alexandre VI, acabou se prejudicando, como Maquiavel explana:

[Luís XII ajudou] o Papa Alexandre a ocupar a Romanha. Nem pensou que, com essa deliberação, se enfraquecia a si próprio, pois afastava dele os amigos e aqueles que se lhe tinham lançado ao seio, e fortificava a Igreja, ajuntando ao poder espiritual, que já lhe dá tanta autoridade, uma tão grande cópia de poder temporal. (1983, pp.13-14)

Sendo possível verificar que a questão não é a impossibilidade de haver uma intersecção entre Estado e Igreja só pelo fato de uma prejudicar a outra em determinados acordos, o que deve ser notado é que justamente por uma prejudicar a outra, é que ambas desejam todo o poder apenas para uma delas. Em Maquiavel é possível notar seu anseio de atribuir poder integral e total ao Estado, a fim de restringir o poder da Igreja: “(...) dizendo-me ele que os italianos não entendiam de guerra, expliquei-lhe que os franceses não entendiam do Estado, pois se entendessem não teriam consentido à Igreja tanta grandeza" (1983, p. 15).

Após tecer inúmeros elogios a César Bórgia, que, mesmo com ânimo acabou sucumbindo, Maquiavel considerou usá-lo como exemplo de bravura. Uma das situações que mostram tamanha influência do Estado sobre a Igreja e vice-versa, é a possibilidade de César Bórgia, enquanto duque de alta influência, interferir no resultado da eleição de um novo papa. Como consequência política, ele acabou ofendendo pessoas que estavam diretamente interessadas na eleição do papa que César Bórgia evitou ser eleito:

Só é possível acusá-lo quanto à criação de Júlio pontífice, a qual escolha foi má, pois, como se disse, não podendo fazer papa a quem queria, podia evitar que o fosse quem não quisesse. Não deveria ele ter consentido jamais no papado de um dos cardeais a quem tivesse ofendido ou que, feito pontífice, tivesse de temê-lo. Pois os homens ofendem ou por medo ou por ódio. (MAQUIAVEL, 1983, p. 32). 
Diante deste cenário, é possível perceber a correlação de forças entre Estado e Igreja. César Bórgia interveio no resultado da eleição papal, como consequência ele ajudou a eleger quem ele queria, porém, sofreu muitos contratempos para manter sua posição, "o duque errou, pois, nessa eleição, e foi ele mesmo o causador de sua ruína definitiva" (MAQUIAVEL, 1983, p. 33).

Maquiavel também explicita a relação da Igreja com o Estado quando classifica como principado eclesiástico - aqueles que se dedicam a trabalhar na administração de interesses da Igreja, papas, bispos, padres e afins. Ou seja, a Igreja não é nada além que relações humanas, as quais se utilizam da crença da população para validar sua potência e poder. Sendo mais preocupante, já que colocam para si desígnios sobrenaturais, e não atributos humanos - sendo estes defendidos por Maquiavel ao longo de seu escrito, como a virtù e a fortù. "E sendo eles regidos por poderes superiores, aos quais, a razão humana não atinge, deixarei de falar a respeito; estabelecidos e mantidos por um Deus tais Estados, seria de homem presunçoso e temerário agir de outra forma" (MAQUIAVEL, 1983, p. 45). Mesmo que no começo, para que a Igreja ocupasse tal posição, tivessem usado armas, traições, falcatruas, depois de estabelecida, a Igreja só passou a ser vista com uma suposta benevolência, isenta de todo o mal. "E espera-se que, se alguns tornaram o papado poderoso pelas armas, o atual pontífice, pela sua bondade e inúmeras outras virtudes, o torne ainda mais forte e venerando." (MAQUIAVEL, 1983, p. 47). É possível perceber que, apesar de sua aversão para com o poder eclesiástico, Maquiavel não pode negar sua existência, e o meio perverso que a mesma se utiliza para convencer que seu poderio é justificável, onde elas não se utilizam das vias mais eficazes para manter-se no poder: a virtù e fortù. Eles colocam poderes tão enfatizados para si - como qualquer outro príncipe colocaria - que "as suas instituições tornam-se tão fortes e de tal natureza que sustentam os seus príncipes no poder, vivam e procedam eles como bem entenderem" (MAQUIAVEL, 1983, p.45, grifo meu).

Lutero, entretanto, via a necessidade de o príncipe se submeter à vontade divina, tendo quatro formas de ajudar a si próprio: 1) ter confiança real em Deus; Ele é a maior autoridade a ser obedecida. 2) dar amor e auxílio ao seus súditos; 3) ter uma boa relação com seus conselheiros e súditos; 4) ter clarividência ao punir devidamente somente os facínoras. Vivendo e agindo dessa forma, ele agrada não só a Deus, mas também aos seus súditos, e eles devem estar preparados para sofrer por tamanha generosidade.

Para Lutero, era possível que o príncipe secular fosse um bom cristão, e, por conseguinte, governasse melhor. Para sê-lo, em primeiro lugar, precisava ver seus súditos 
como pessoas a quem deveria ajudar; e não pensar, pretensamente, que os súditos fossem seus e as terras também, podendo fazer o que bem entendesse com eles. Sempre deveria colocar a vontade dos súditos em primeiro lugar, posição totalmente contrária à visão maquiavélica: "Havia [...] no duque tão grande energia e valor, bem sabendo ele que os homens se conquistam ou se exterminam, e eram tão sólidos os alicerces construídos para o seu poderio(...)" (MAQUIAVEL, 1983, p. 31).

\section{Referências Bibliográficas:}

LUTERO, Martinho. Da Liberdade do Cristão: prefácios à Bíblia. Tradução de Erlon José Paschoal. São Paulo: Editora UNESP, 1998.

Sobre a Autoridade Secular. Tradução de Hélio de Marco Leite de Barros, Carlos Eduardo Silveira Matos. $2^{\circ} \mathrm{Ed}$. São Paulo: Martins Fontes, 2005.

MAQUIAVEL, Nicolau. O Príncipe. Tradução de de Lívio Xavier. $3^{\text {a }}$ Ed. São Paulo: Abril Cultural, 1983. (Os Pensadores).

SKINNER, Quentin. As Fundações do Pensamento Político Moderno. Tradução de Renato Janine Ribeiro e Laura Teixeira Motta. São Paulo: Companhia das Letras, 1996. 